\title{
MICROENCAPSULATION TECHNIQUE WITH ORGANIC ADDITIVES FOR BIOCONTROL AGENTS
}

\author{
Magdalena SZCZECH*, Robert MACIOROWSKI \\ Research Institute of Horticulture \\ Konstytucji 3 Maja 1/3 str., 96-100 Skierniewice, Poland \\ Received: March 2016; Accepted: May 2016
}

\begin{abstract}
The aim of these studies was to develop an effective formulation for microbial strains active in plant protection. Emulsification technique in oil was used to produce alginate microcapsules supplemented with organic additives to improve production process and stability of the preparations during storage. The release of microorganisms from the capsules in soil and their effectiveness in biocontrol of Fusarium wilt were evaluated. Three bacterial strains Burkholderia cepacia strain CAT5, Bacillus spp. strains PZ9 and SZ61, and fungus Trichoderma virens TRS106 were immobilized separately in calcium alginate supplemented with chitosan, peat powder, or skim milk. The productivity of microcapsules was enhanced by $60 \%$ when peat was added to the alginate matrix. Peat reduced also contamination of the capsules during storage, significantly enhancing their quality. By contrast, the addition of skim milk reduced quality of the microcapsules. The additives did not influence the viability of entrapped microorganisms and their release in soil. The survival of the microbial cells was mainly related to the kind of microorganism used, and the highest viability showed Bacillus sp. PZ9 and Trichoderma TRS106. Lyophilization of the microcapsules appeared to be unfavorable by reducing microbial viability in the capsules and in the soil after application. The best properties: good storage ability and sufficient microbial release in the soil, exhibited wet microcapsules amended with peat. These capsules were used to control Fusarium wilt in tomato plants. The protective effect was obtained when the microcapsule-entrapped bacteria PZ9 were used. The effectiveness of this bacterium was comparable with fungicide. Peatamended microcapsules entrapping Bacillus PZ9 showed the best quality and may have potential for commercial use.
\end{abstract}

Key words: microencapsulation, organic additives, microorganisms viability, storage ability

\section{INTRODUCTION}

The changes in public concern about protection of the environment impact the agricultural practices by limiting the use of chemical fertilizers and pesticides. As an alternative, soil-bio-amendments are proposed, including microorganisms used as plant growth promoters or biocontrol agents. Despite intensive investigation, many potentially useful bacteria or fungi, reported in literature, never appeared in the commercial market. Microorganisms applied in the field encompass many problems with respect to unpredictable en- vironmental conditions. They have to face competition of better-adapted indigenous microorganisms, variable temperatures, draught, unfavorable $\mathrm{pH}$, adsorption by soil particles, or washing-off by rain (Bashan 1986; Winder et al. 2003; Young et al. 2006; Guo et al. 2012). Therefore, for commercial use, microbial inoculum should be supported by appropriate formulation preventing a rapid decline of introduced microorganisms and extending their shelf-life. A number of formulation technologies, based on various carriers, were developed for application in agriculture (Cassidy et al. 1996; Bashan 1998; Schisler et al. 2004; John et al. 2011; 
Vemmer \& Patel 2013). Among the carriers, alginate, a biopolymer derived from the macroalgae, is widely used (Yabur et al. 2007). Its production is massive and cheap. This material is non-toxic, consistent in quality, nearly sterile, and biocompatible with microorganisms. Alginate may be dissolved in water or in liquid microbial culture, and in contact with solution of di- or tri-cations, it forms thermally stabile hydrogel globules called "beads"(Chan et al. 2011). In the past decades, several experimental microbial formulations with alginate have been evaluated as inoculants for agriculture to improve plant productivity (Bashan 1998; Young et al. 2006; Yabur et al. 2007; Minaxi \& Saxena 2011), for wastewater treatments (Cassidy et al. 1996), for entrapping of microbial cells in the food industry (Krasaekoopt et al. 2003; Onwulata 2012; Tripathi \& Giri 2014), or for pharmaceutical and medical applications (Hunt \& Grover 2010; Cook et al. 2012). Encapsulated with alginate Pseudomonas fluorescens showed significantly increased survival rates over free cells in soil (Trevors et al. 1992), and shelf life of pro-biotic culture of Bifidobacterium bifidum, and Lactobacillus acidophilus was stabilized during 90 days of storage (Özer et al. 2008).

In the Research Institute of Horticulture (Skierniewice, Poland), several bacterial and fungal strains were selected as biocontrol agents and plant growth promoters (Szczech \& Dyki 2007, 2008; Szczech et al. 2009, 2011). In these studies, different bacteria: Burkholderia cepacia strain CAT5, Bacillus spp. strains PZ9 and SZ61, and fungal strain TRS106 (Trichoderma virens sp.) were chosen to develop a formulation technique of active microorganisms for application in vegetable production. Strain CAT5 produced antibiotic pyrrolnitrin and inhibited the growth of fungal pathogens for example Fusarium spp. and Rhizoctonia solani (Szczech 2009). This strain increased tomato germination in soil infested with multiple pathogens, plant biomass and xylem thickness, and phenolic compounds content in roots of tomato plants (Szczech 2009; Szczech et al. 2009). Bacteria PZ9 and SZ61 promoted the growth of tomato and cucumber plants even in growing media infested with pathogens (Szczech 2009). Strain PZ9 was effective in the production of lettuce transplants, significantly increasing their biomass and root development (Szczech data prepared for publication). Trichoderma TRS106 induced resistance in tomato and cucumber plants (Nawrocka et al. 2011). It was also proved that its application in the growing media significantly increased the lycopene concentration in tomato fruit (Szwejda-Grzybowska et al. 2015). For formulation of these microorganisms, the microencapsulation technique based on the emulsification of alginate/microbial cell mixture was chosen.

Microcapsules are reported as an efficient and convenient method for microorganisms preservation and application (Rathore et al. 2013). The size of capsules ranging 1-1000 $\mu \mathrm{m}$ (Bashan et al. 2002). However, they are capable of entrapping a sufficient number of microbial cells. Bashan et al. (2002) inoculated seeds with plant growth-promoting Azospirillum brasilense, encapsulated in alginate microbeads, of which diameter ranged between 100-200 $\mu \mathrm{m}$, and the density of bacteria was $10^{11} \mathrm{cfu}^{-1} \mathrm{~g}^{-1}$ of the capsules. The small size of the capsules provides efficient diffusion of oxygen, nutrients, and metabolites, which permits a high cell concentration and viability, while the number of viable cells entrapped in larger beads is low due to limited diffusion of oxygen into the bead center. Ogbonna et al. (1991) have found that the optimum bead size for oxygen penetration in different polymeric beads was 100 $300 \mu \mathrm{m}$. With microcapsules, it is possible to produce a powder-like formulation, which enables more uniform and efficient distribution in soil, dispersion on the foliage, and seed coating.

Emulsification is considered relatively easy and reliable method for microcapsule production (Winder et al. 2003; Vemmer \& Patel 2013; Tripathi \& Giri 2014). This technique is based on the emulsification of cell/polymer suspension in an oil/organic medium (Rathore et al. 2013). The addition of calcium chloride as a cross-linking agent to the emulsion, with continuous stirring, results in the production of micro-hydrogel globules, which may be then harvested by filtration. The incorporation of additional components into the polymer matrix or coating of the capsules with them have been shown to enhance cell viability, stability of the alginate capsules and improved storage ability of encapsulated microorganisms (Krasaekoopt et al. 2004). 
The aim of this work was to develop an encapsulation method for preservation and agricultural application of selected active bacteria and fungi. The studied technique comprised enrichment of microcapsules with different organic additives to provide satisfactory viability of the microorganisms and quality of the product. Batches of produced microcapsules were lyophilized to enhance their stability. The efficiency of the microcapsule production process with the additives, cell viability in different types of the capsules, and storage ability were studied. Then, the rate of microbial release from the microcapsules in soil and their potential to control Fusarium were investigated.

\section{MATERIALS AND METHODS}

Bacterial strains CAT5 (Burkholderia cepacia), PZ9, and SZ61 (Bacillus spp.) and fungal strain TRS106 (Trichoderma virens) were taken from the collection of Laboratory of Microbiology in the Research Institute of Horticulture in Skierniewice, Poland. Bacteria were grown in the flasks with $100 \mathrm{ml}$ of nutrient broth on the rotary shaker (200 rpm), for $48 \mathrm{~h}$ at $30^{\circ} \mathrm{C}$. The cell density in the culture was estimated using the serial dilution plating method on nutrient agar (Merck) after incubation at $30{ }^{\circ} \mathrm{C}$ for $48 \mathrm{~h}$. The final concentrations of the bacteria in the cultures were as follow: CAT5 $10^{10} \mathrm{cfu} \cdot \mathrm{ml}^{-1}$; PZ9 $10^{10} \mathrm{cfu} \cdot \mathrm{ml}^{-1}$; and SZ61 $10^{11} \mathrm{cfu} \cdot \mathrm{ml}^{-1}$. The conidia of Trichoderma TRS106 were harvested from the surface of 10-day-old fungal culture on malt agar medium (Fluka) in the Petri plate $(90 \mathrm{~mm})$. The conidia were suspended in $10 \mathrm{ml}$ of $0.85 \%$ sterilized solution of sodium chloride. The aliquot of such suspension was added to the sterilized sodium chloride solution to obtain $100 \mathrm{ml}$ of the suspension containing $10^{8}$ conidia $\cdot \mathrm{ml}^{-1}$. The density of conidia was estimated with the use of a hemocytometer.

Alginate microcapsules were prepared according to the modified emulsification method described by Winder et al. (2003). All the glassware, solutions, and oil used in the protocol were sterilized at $121^{\circ} \mathrm{C}$ for $20 \mathrm{~min}$ prior to use. The entrapment of bacterial cells and fungal spores was carried out under sterile conditions in a laminar flow hood. To prepare the microcapsules, bacterial culture $(100 \mathrm{ml})$ was mixed with $2 \mathrm{~g}$ of sodium alginate powder (Sigma) and agitated with magnetic stirrer for $60 \mathrm{~min}$ at ambient temperature. The bacterial concentration in the culture at this stage ranged from $10^{10}$ to $10^{11} \mathrm{cfu} \cdot \mathrm{ml}^{-1}$ according to the used strain of the bacteria. To produce microbeads containing conidia of $T$. virens TRS106, $100 \mathrm{ml}$ of conidial suspension $\left(10^{8} \mathrm{cfu} \cdot \mathrm{ml}^{-1}\right)$ was applied. After sodium alginate was dissolved, $100 \mathrm{ml}$ of sunflower oil was added to emulsify the bacterial culture/alginate mixture. The mixture was emulsified using a mechanical hand blender with a steel whisk for $1 \mathrm{~min}$. The emulsion was gradually poured with $200 \mathrm{ml}$ of an aqueous solution of $0.1 \mathrm{M} \mathrm{CaCl}_{2}$, continuously agitated with blender. After the solution of $\mathrm{CaCl}_{2}$ was added, soluble sodium alginate was converted into water-insoluble calcium alginate microbeads. The microbeads were allowed to harden for $60 \mathrm{~min}$ at room temperature under constant agitation on a magnetic stirrer. The microbeads were collected by vacuum filtration under aseptic conditions and stored wet in sterile, closed jars (vol. $125 \mathrm{ml}$ ) at $4{ }^{\circ} \mathrm{C}$.

For the production of supplemented microcapsules, the following organic additives were used: peat, chitosan (Sigma), and skim milk (Sigma). Peat was dried at $60^{\circ} \mathrm{C}$, sieved by $1 \mathrm{~mm}$ sieve, autoclaved at $121^{\circ} \mathrm{C}$ for $20 \mathrm{~min}$, and stored in sterilized jars in dark, dry, and aseptic conditions till use. Skim milk and chitosan were kept in aseptic conditions, in original packaging. One gram of peat or skim milk $(1 \% \mathrm{w} / \mathrm{v})$, and $0.5 \mathrm{~g}$ of chitosan $(0.5 \% \mathrm{w} / \mathrm{v})$ were added to $100 \mathrm{ml}$ of bacterial cultures or $100 \mathrm{ml}$ of TRS106 conidial suspension prior to sodium alginate. After preparation of the alginate-additive-bacterial mixture, the microcapsules were prepared as described earlier. In all microencapsulation processes, for each microorganisms and additive, three batches of microcapsules were prepared in one production cycle. There were minimum three production cycles for each microcapsule type.

After microencapsulation processes, the yield of obtained microcapsules was determined by weighing them separately for all batches, directly after filtration, under aseptic conditions. The diameter of the microcapsules was measured under a light microscope Olympus BX41 using QuickPHOTO Camera 2.3 program. The diameter of 50 microcapsules was measured for each sample under the magnitude 10x. The measurement was repeated three times for the microcapsules obtained in three separate production processes. 
To increase stability and viability of the entrapped microorganisms during storage, the batches of microcapsules were lyophilized. Immediately after microencapsulation, all types of microcapsules ( $25 \mathrm{~g}$ for each type), containing bacterial cells or fungal conidia, were frozen at $-80^{\circ} \mathrm{C}$. After freezing the capsules were lyophilized using lyophilizer ALPHA 2-4 LSC (Christ Gefriertrocknungsanlagen $\mathrm{GmbH}$ ) to complete dryness and kept until usage in hermetically sealed jars (vol. $125 \mathrm{ml}$ ) at $4{ }^{\circ} \mathrm{C}$.

The survival rate of microorganisms in microcapsules was determined directly after encapsulation process and after lyophilization. Then, the viability of bacteria and fungus was analysed after one, three, and six months of capsule storage at $4{ }^{\circ} \mathrm{C}$. The experiment was repeated twice, and all the measurements were performed in three replications. To estimate the microbial viability, the samples of the microcapsules ( $1 \mathrm{~g}$ of wet capsules and $0.1 \mathrm{~g}$ of lyophilized) were dissolved in $10 \mathrm{ml}$ of $0.2 \mathrm{M}$ phosphate buffer ( $\mathrm{pH}$ 6.8) and incubated at $30{ }^{\circ} \mathrm{C}$ for $2 \mathrm{~h}$. To release cells the suspensions were vortexed. The number of bacteria was determined by standard serial dilution plating method on nutrient agar (Merck) after incubation at $30{ }^{\circ} \mathrm{C}$ for $48 \mathrm{~h}$, and the number of Trichoderma TRS106 propagules on rose Bengal agar (Martin 1950) after incubation at $25^{\circ} \mathrm{C}$ for 6 days. The number of microorganisms was expressed as $\mathrm{cfu} \cdot \mathrm{g}^{-1}$ of the dry weight of microcapsules.

During storage, the microcapsules were examined for the degree of contamination using 0-4 index where: 0 - smell typical for fresh product, without discoloration; 1 - not typical smell, light discoloration; 2 - unpleasant smell, distinct discoloration; 3 - strong unpleasant smell, discoloration of most product, visible coatings; and 4 - product with coatings and molds, completely contaminated.

The studies on the rate of microbial release from the produced microcapsules were conducted in growth chamber, in non-sterilized soil mixed with vermiculite ( $1: 1$ vol.). The chemical characteristics of the soil were as follows: $\mathrm{pH}$ 7.2; minerals contents: $49 \mathrm{mg}$ of $\mathrm{N}-\mathrm{NO}_{3}, 66 \mathrm{mg}$ of $\mathrm{P}, 262 \mathrm{mg}$ of $\mathrm{K}, 254 \mathrm{mg}$ of $\mathrm{Mg}, 808 \mathrm{mg}$ of $\mathrm{Ca}$ in one liter of soil. The soil/vermiculite was mixed with wet or lyophilized microcapsules containing bacteria CAT5 or spores of T. virens TRS106, supplemented with different additives. For this experiment, microcapsules with bacteria CAT5 and Trichoderma TRS106 were chosen because of reliable isolation of these microorganisms from non-sterile soil using selective media. Wet microcapsules were added to the soil at a dose of $500 \mathrm{mg} \cdot 100 \mathrm{~g}^{-1}$, and lyophilized microcapsules at a dose of $250 \mathrm{mg} 100 \mathrm{~g}^{-1}$ of the soil. To the inoculated soil sterilized water was added to obtain $60 \%$ of the water holding capacity, and was distributed to plastic micropots (100 $\mathrm{g}$ of the soil per pot). Eight pots were prepared for each treatment. As a control, pots filled with soil without microcapsules were used. The pots were kept in a growth chamber at $25^{\circ} \mathrm{C}, 90 \%$ humidity, in dark. During incubation, the soil was watered to maintain the moisture at $60 \%$.

The soil was sampled and analysed for the number of bacteria CAT5 and fungal propagules 4,10 , and 30 days after incubation. At each sampling time, three random samples (10 $\mathrm{g}$ from one pot) for each treatment were collected. The number of CAT5 and TRS106 was determined using standard serial dilution plating method, respectively on: CB medium selective for Burkholderia (Wu \& Thompson 1984) and Rose Bengal medium for fungi. The colonies of CAT5 were counted after $48 \mathrm{~h}$ of incubation at $30^{\circ} \mathrm{C}$, and for TRS106 after 7 days of incubation at $25^{\circ} \mathrm{C}$. The experiment was repeated three times.

To check the efficacy of the encapsulated microorganisms on their potential to suppress the tomato disease the greenhouse experiment in three repetitions was carried out. Tomato plants 'Remiz $F_{1}$ ' were grown in pots of $0.5 \mathrm{dm}^{3}$ filled with the soil/vermiculite mixture infested with conidia of pathogenic fungus Fusarium oxysporum f. sp. lycopersici, the cause of Fusarium wilt of tomato. This soil was autoclaved prior to inoculation and added with sterilized water to obtain $60 \%$ of the water holding capacity. For conidial production, $F$. oxysporum was grown on PDA in Petri dishes, in the dark at $25^{\circ} \mathrm{C}$ for 10 days. The conidia were scratched off the medium surface and suspended in $0.85 \% \mathrm{NaCl}$ solution. The conidial density was measured with the use of hemocytometer. The aliquot of conidial suspension was added to the soil mixture to obtain the final Fusarium density $10^{3} \mathrm{cfu} \cdot 100 \mathrm{~g}^{-1}$ of the soil. Infested soil was mixed with microcapsules containing bacteria PZ9, SZ61, CAT5, and spores of TRS106 at a dose of $50 \mathrm{mg} \cdot 100 \mathrm{~g}^{-1}$. For this experiment, wet 
microcapsules amended with peat were chosen. The soil mixture not infested with the pathogen and without microcapsules served as a control. The soil in pots was sown with one tomato seed per pot. As a chemical control, seeds were coated with fungicide Zaprawa Nasienna T 75DS/WS (thiram 75\%) and planted into pots with soil infested with Fusarium. For each experiment six pots were prepared for treatment. Tomato plants were grown for 4 weeks in the greenhouse and were watered to keep the moisture at $60 \%$. Fusarium wilt was estimated by measuring the fresh weight of aboveground parts of plants. The number of Fusarium propagules in soil was estimated at the end of each experiment. Three random soil samples ( $10 \mathrm{~g}$ each) for each treatment were collected from the pots in the consecutive experiments. The number of Fusarium spp. colonies was determined after 2 weeks of incubation at $25{ }^{\circ} \mathrm{C}$, using standard serial dilution plating method on selective Komada medium (Komada 1975).

As experimental factors, dependent on the experiment, kind of organic additives, encapsulated microorganism, type of microcapsules, time of storage, and time of incubation have been tested in multi-factorial ANOVA models. Before ANOVA, the homoscedasticity and normality assumptions were tested by means of Levene's and Shapiro-Wilk tests, respectively. The means for significant effects were compared using Duncan Multiple Range Test (DMRT) at $p=0.05$. All calculations were done using statistical software package STATISTICA v. 10 (StatSoft, Inc. 2011).

\section{RESULTS AND DISCUSSION}

Developing of an effective inoculants for plants, soil or growing media, containing beneficial microorganisms is still a challenge in the commercial production and agricultural application. The main task is to obtain a uniform and stable product during storage, with consistent efficacy. It is difficult because microorganisms are very sensitive to processing and environmental factors. In this work, an emulsification technique was used to produce alginate microcapsules entrapping the microorganisms. It was found that the components incorporated into alginate matrix during encapsulation had a significant effect on the yield and size of the capsules (Table 1). The most effective production was obtained when peat or chitosan were added to the dispersed phase. The weight of the harvested microcapsules supplemented with peat was $60 \%$ and with chitosan $42 \%$ higher than the yield of microcapsules without amendments. Addition of skim milk had no effect on the yield and diameter of microcapsules. Moreover, the application of skim milk made the production of microcapsules more difficult, mainly due to less effective separation from oil phase.

The capsules containing peat and chitosan were also bigger than those with skim milk and not supplemented and their average diameter was about $50 \mu \mathrm{m}$ (Table 1). The smallest microcapsules and the most uniform in size were produced with skim milk. Generally, the size of obtained microcapsules ranged from 10-110 $\mu \mathrm{m}$. According to literature, the incorporation of certain components into the alginate matrix, such as clay, skim milk, chitosan, sugars, gum acacia, or maize starch, has been shown to improve the quality of the capsules (Bashan 1998; Krasaekoopt et al. 2004). Lin et al. (2008) have shown that chitosan enhanced the mechanical resistance and stability of alginate beads. Young et al. (2006) reported that beads enriched with humic acid were regular and spherical in shape with a diameter ranging between 2-3 mm. The supplementation of capsules with skim milk was recommended by Bashan $(1986 ; 1998)$ and Bashan et al. (2002); however, in our case, this additive was not effective, and significantly reduced the quality of the product.

It was also found that the type of encapsulated microorganism had also an impact on the capsule size and productivity. A significantly higher yield of microcapsules was obtained for bacteria Bacillus spp. strains PZ9 and SZ61 (Table 1). The lowest yield was for B. cepacia CAT5 and spores of Trichoderma TRS106. The encapsulation of bacteria PZ9 resulted in a bigger capsule diameter compared to other microorganisms. 
Table 1. The yield and diameter of the microcapsules according to the organic additives and type of encapsulated microorganism

\begin{tabular}{lcc}
\hline \multicolumn{1}{c}{ Components } & Yield $^{\mathrm{a}}(\mathrm{g})$ & Capsule diameter $(\mu \mathrm{m})$ \\
\hline organic additives to alginate matrix & & \\
\hline alginate without additives & $42.3 \mathrm{~b}$ & $43.2 \mathrm{~b}$ \\
chitosan & $62.2 \mathrm{a}$ & $49.5 \mathrm{ab}$ \\
peat & $69.0 \mathrm{a}$ & $50.5 \mathrm{a}$ \\
skim milk & $42.9 \mathrm{~b}$ & $42.9 \mathrm{~b}$ \\
\hline encapsulated microorganism & & \\
\hline Bacillus spp. PZ9 & $59.8 \mathrm{a}$ & $56.5 \mathrm{a}$ \\
Bacillus spp. SZ61 & $64.1 \mathrm{a}$ & $39.5 \mathrm{~b}$ \\
Burkholderia cepacia CAT5 & $48.8 \mathrm{~b}$ & $49.2 \mathrm{a}$ \\
Trichoderma virens TRS106 & $43.6 \mathrm{~b}$ & $41.9 \mathrm{~b}$ \\
\hline
\end{tabular}

${ }^{a}$ Yield of microcapsules produced from $100 \mathrm{ml}$ of culture with $2 \%(\mathrm{v} / \mathrm{w})$ sodium alginate and supplemented with $1 \%(\mathrm{v} / \mathrm{w})$ of additives. The values are the means of the nine replicates. The means within the column with the same letters for each factor do not differ significantly according to DMRT at $\mathrm{p}=0.05$.

Alginate beads are capable of entrapping high number of bacteria, and the cell density may reach $10^{11} \mathrm{cfu} \cdot \mathrm{g}^{-1}$ of the bead (Bashan et al. 2002; Young et al. 2006). In our studies similar result was obtained. The survival of entrapped microorganisms was examined immediately after encapsulation process was completed, and the capsules were harvested by filtration. It was found that the number of viable cells in the microcapsules (Table 2) was comparable with the initial concentration of bacterial cells and fungal spores in the cultures used for encapsulation $\left(10^{10} \mathrm{cfu}\right.$ for PZ9 and CAT5, $10^{11} \mathrm{cfu}$ for SZ61, and $10^{8} \mathrm{cfu}$ for TRS106). There were not significant differences in the number of viable cells in the microcapsules supplemented with additives (data not presented). It suggests that the used method of emulsification in plant oil did not reduce the viability of the encapsulated microorganisms, and the supplementation of the alginate matrix with additional compounds did not influence the microbial load in microcapsules and cell viability after processing. It is opposite to observation of Bashan et al. (2002), who reported that the entrapping procedure during microbeads production kills a large number of bacteria because of cross-linking of the alginatecalcium complex with the bacterial cell wall. On the other hand, the addition of clay and skim milk to alginate beads significantly increased the bacterial survival over alginate alone (Bashan 1998).

Lyophilization is a method recommended for different applications and for long-term storage of microorganisms (Morgan et al. 2006; Semyonov et al. 2010). Therefore, to improve storage qualities of the capsules, a part of them was lyophilized. However, the viability of microorganisms in dried microcapsules was drastically reduced (Table 2 ). The most resistant to lyophilization was bacteria PZ9, while the density of viable spores of Trichoderma TRS106 decreased from $10^{8} \mathrm{cfu} \cdot \mathrm{g}^{-1}$ to $10^{5} \mathrm{cfu} \cdot \mathrm{g}^{-1}$. To reduce this undesirable effect, protective agents can be used. For example, starch filler added to alginate beads containing $L$. casei improved their strength and stability during lyophilization, and the cell viability was 100 times higher than in the beads without starch (Chan et al. 2011). However, in our studies, organic additives incorporated into the alginate matrix did not protect the entrapped microorganisms from the loss of viability during lyophilization (data not presented). Lyophilization, an expensive process, seems to be not suitable for the development of a commercial product in this case.

Table 2. Mean counts of the studied microorganisms in microcapsules $\left(\log \mathrm{cfu} \cdot \mathrm{g}^{-1} \pm \mathrm{SE}\right)$ immediately after encapsulation and after lyophilization

\begin{tabular}{ccccc}
\hline Type of mi- & \multicolumn{4}{c}{ Encapsulated microorganisms } \\
\cline { 2 - 5 } crocapsules & PZ9 & SZ61 & CAT5 & TRS106 \\
\hline after en- & $10.40 \mathrm{a} \pm$ & $10.83 \mathrm{a} \pm$ & $10.98 \mathrm{a} \pm$ & $8.46 \mathrm{a} \pm$ \\
capsulation & 0.09 & 0.31 & 0.12 & 0.07 \\
\hline \multirow{2}{*}{ lyophilized } & $9.62 \mathrm{~b} \pm$ & $9.01 \mathrm{~b} \pm$ & $9.41 \mathrm{~b} \pm$ & $5.50 \mathrm{~b} \pm$ \\
& 0.15 & 0.17 & 0.22 & 0.16 \\
\hline
\end{tabular}

The values are the means of the nine replicates. The means within the column with the same letters do not differ significantly according to DMRT at $\mathrm{p}=0.05$. 
The maintenance of cell viability during longer storage of microbial preparations is crucial to develop a commercial product. Bashan and Gonzales (1999) kept dried alginate beads containing PGPR Azospirillum brasilense and Pseudomonas fluorescens for 14 years at ambient temperature. The population of both bacteria had decreased, but a significant number of viable cells were still detected after such long time. However, they found that $P$. fluorescens was less durable than A. brasilense. Similarly, in our studies, the kind of entrapped microorganism had a marked effect on the product durability (Fig. 1). Instead, the viability of the studied microorganisms was little related to the type of microcapsules (wet or lyophilized, except for Trichoderma) and to the used organic additives (Fig. 3). The highest storage potential had conidia of Trichoderma fungus. In lyophilized capsules, TRS106 survived at almost the same level for half a year. In wet microcapsules, the reduction of viable conidia number was noted in the sixth month of the storage, but still load of the fungus was high $-10^{7} \mathrm{cfu} \cdot \mathrm{g}^{-1}$. Bacteria were less resistant to the storage conditions. The reduction of viable cells was observed after one month, and it progressed in wet as well as in lyophilized microcapsules (Fig. 1). After six months of storage, the number of detected bacterial cells was reduced for about $2 \log \mathrm{cfu} \cdot \mathrm{g}^{-1}$. However, there were differences between encapsulated strains. PZ9 had the best storage ability in wet and dried microcapsules. The loss of PZ9 viability was continuous but slower than in the case of other studied bacteria. Good potential was also obtained with CAT5. However, after three months, the number of viable cells of this strain decreased rapidly, especially in lyophilized microcapsules. Bacteria SZ61 was not stable during storage, despite of the type of the microcapsules and used additives. It was noted that after 1 month, the microcapsules with SZ61 were contaminated, and this process progressed, what falsified the microbial count. A microscopic observation revealed not regular shape and disintegrated structure of these microcapsules, while capsules with PZ9 and CAT5 were coherent and round or oval. Such structure was probably not efficient to protect entrapped cells of SZ61.
The incorporation of additional components into the alginate matrix did not change the viability of the microorganisms in the microcapsules (Fig. 3). In the literature, there are reports indicating positive or negative effects of the amendments: Bashan and Gonzales (1999) observed a greater reduction of bacterial survival in beads supplemented with skim milk, while humic acid incorporated into alginate beads containing Bacillus subtilis CC-pg. 104 provided high viability of encapsulated bacteria for five months (Young et al. 2006). However, the composition of microcapsules had a significant effect on the contamination degree and shelf life quality, especially for wet products. Lyophilized microcapsules were free from contamination during all storage time (data not shown). In wet microcapsules, the first symptoms of spoilage were generally observed after three months, but addition of peat to alginate significantly reduced the contamination (Fig. 2). The reduction of contamination was also obtained when chitosan was used. Instead, the supplementation of microcapsules with skim milk had deleterious influence on their storage abilities (Fig. 2). The capsules were intensively colonized by bacteria and yeasts, causing strong discolorations, coatings, and unpleasant smell. After one month they were not suitable to use.

A task for microorganism capsulation is not only to secure them during storage, but also after application into a predestined environment. In most cases, the population density of microorganisms introduced to soil or plant rhizosphere declines over time. Therefore, their efficacy may be reduced. It was proved that encapsulated bacteria better survive in soil than free cells (van Elsas et al. 1992; Guo et al. 2012). Cells are gradually released from the capsules by matrix degradation; therefore, they are more protected against destructive factors than not coated microorganisms (Young et al. 2006; Vemmer \& Patel 2013). Controlled release of the biocontrol agent Pantoea agglomerans strain E325 from microcapsules and satisfactory colonization of apple flowers stigma by these bacteria were reported by Kim et al. (2012). However, Bashan et al. (2002) suggested that different polymers or type of beads may have various degradability in soil and may release entrapped microorganisms at different rates. For this 
reason, the ability of alginate microcapsules, containing different organic additives, to release microbial agents in non-sterile soil conditions was studied. The wet and lyophilized alginate microcapsules, contained bacteria CAT5 or conidia of TRS106 were mixed with soil to examine the number of released microorganisms during incubation time. After 4 days of incubation of wet capsules in the soil, the number of CAT5 was about $10^{7} \mathrm{cfu} \cdot \mathrm{g}^{-1}(7.5 \mathrm{log} \mathrm{cfu})$ and TRS106 $10^{5} \mathrm{cfu} \cdot \mathrm{g}^{-1}$ (5.5 log cfu) (Fig. 3). The population of both microorganisms was maintained at this level for all time of the experiment. When lyophilized microcapsules were added to the soil, the number of CAT5 significantly decreased after 10 days (Fig. 3). At the beginning of the experiment, it was about $6.2 \log \mathrm{cfu} \cdot \mathrm{g}^{-1}$, while after 30 days, the population decreased to $4.9 \log \mathrm{cfu} \cdot \mathrm{g}^{-1}$. In the case of Trichoderma TRS106, the density of propagules in soil declined insignificantly from 3.7 to $2.9 \mathrm{log}$ $\mathrm{cfu} \cdot \mathrm{g}^{-1}$. It should be mentioned that the initial density of cells introduced with lyophilized microcapsules was lower than after the application of wet microcapsules (about $10^{6} \mathrm{cfu}^{-1} \mathrm{~g}^{-1}$ for CAT5 and $10^{4} \mathrm{cfu} \cdot \mathrm{g}^{-1}$ for TRS106). There were two reasons: the number of viable cells in dry capsules was much lower due to reduction after lyophilization, and the dose of lyophilized preparation added to the soil was lower than for the wet one. The dose of dry capsules had to be reduced, because the volume of weight equivalent of these capsules compared to wet capsules was too big for soil application and not acceptable. Probably, the lower number of viable cells added with the lyophilized microcapsules might be one of the reasons of CAT5 reduction in non-sterilized soil, where they lost competition with native microorganisms. Trichoderma fungi are more resistant to such competition (Atanasova 2014). It was observed that the capsules added with skim milk indicated tendencies to release a higher number of entrapped bacteria than other microcapsules. Similar result was obtained by Bashan et al. (2002). Incorporation of peat and chitosan into the alginate matrix did not affect the level of microorganisms released to the soil compared with that without additives.
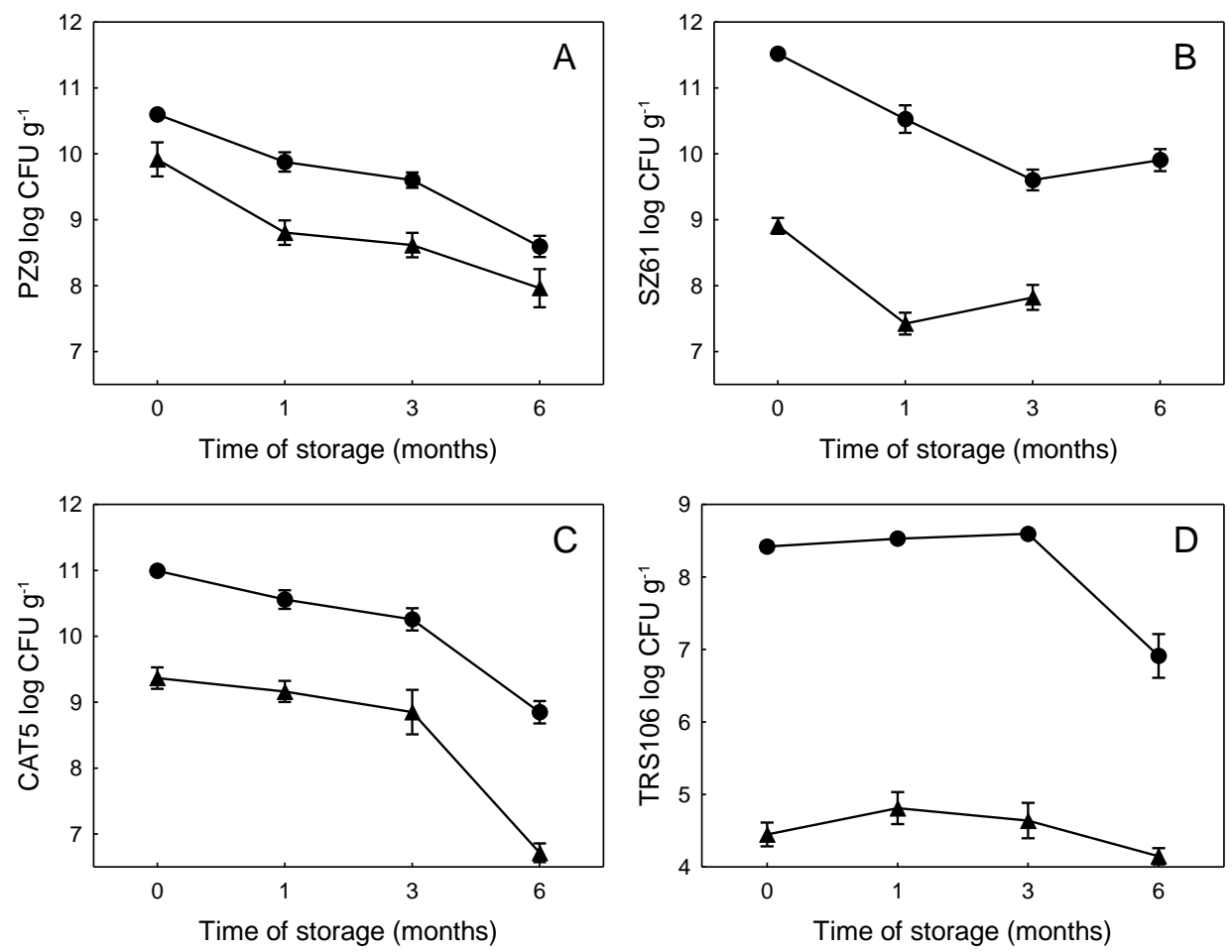

Fig. 1. Survival of different microorganisms during storage at $4{ }^{\circ} \mathrm{C}$ in wet $(\bullet)$ and lyophilized (A) microcapsules: A - Bacillus spp. PZ9, B - Bacillus spp. SZ61, C - B. cepacia CAT5, and D - T. virens TRS106. The vertical bars represent standard error of the means $(n=9)$. 

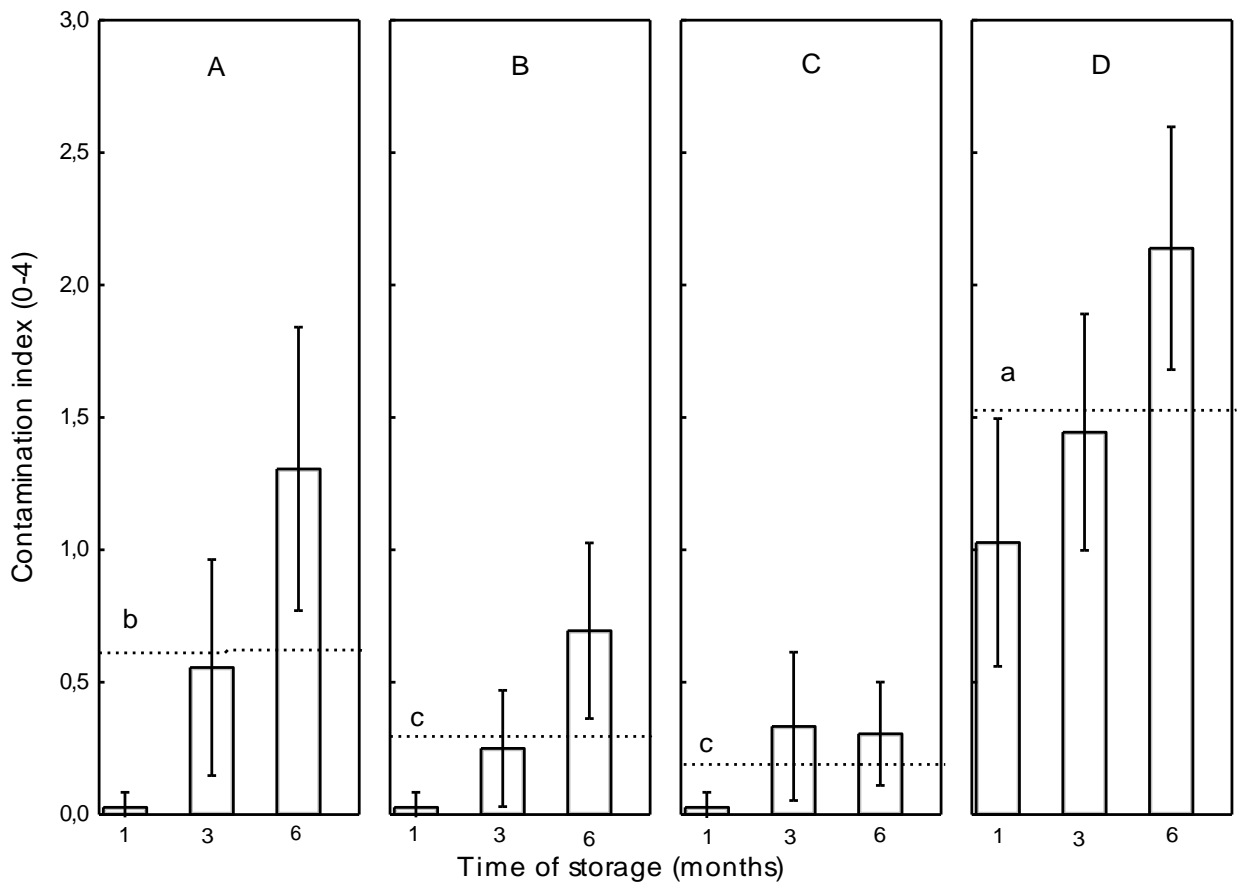

Fig. 2. Degree of wet microcapsules contamination during storage according to the kind of additives (A - alginate. B - chitosan. C - peat. D - skim milk). The vertical bars represent standard error of the means $(n=9)$. The horizontal dotted lines represent the average value for additives over time of storage. The small letters represent homogenous groups for the kind of additives according to DMRT at $\mathrm{p}=0.05$.
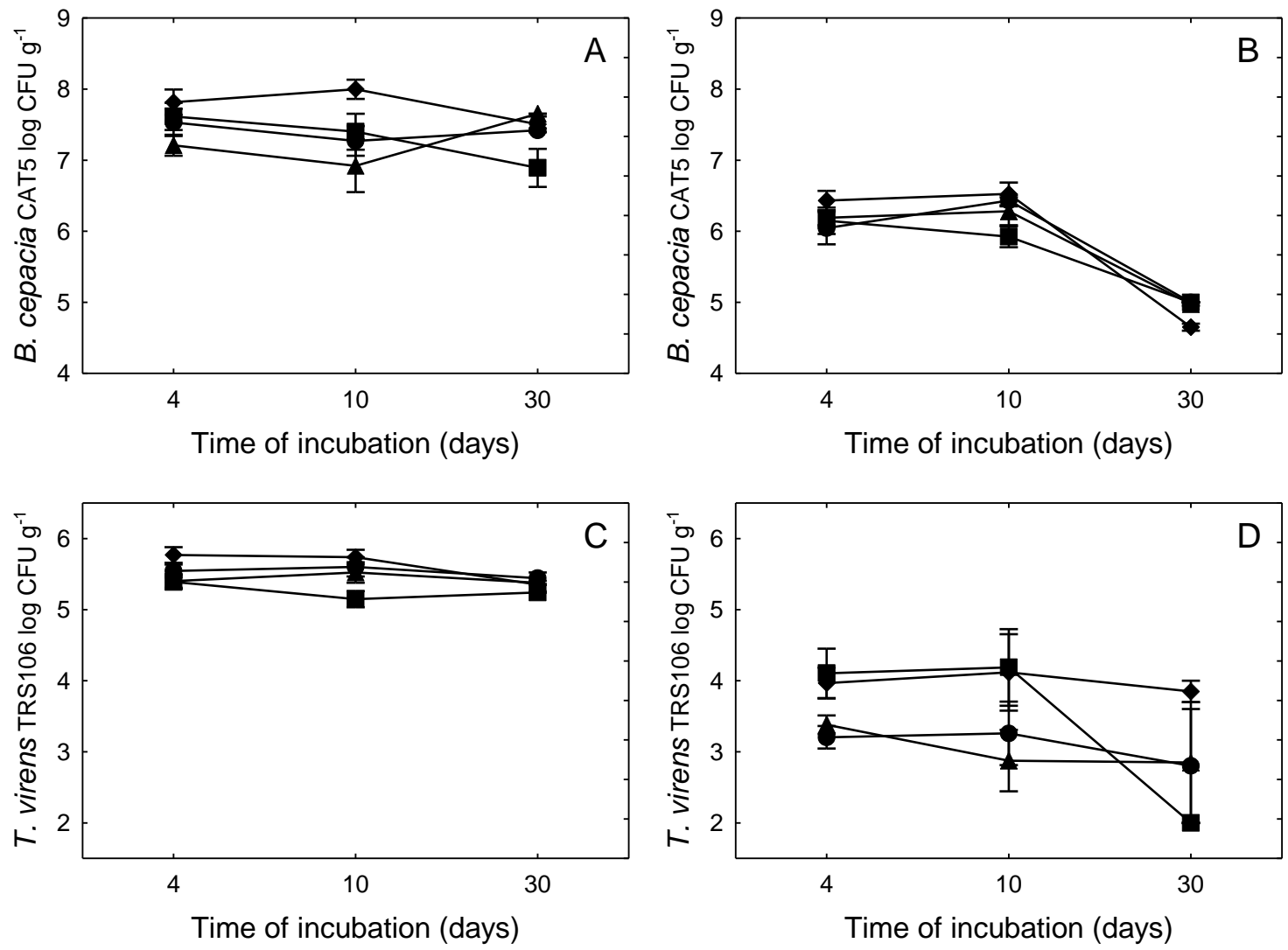

Fig. 3. The number of B. cepacia CAT5 and T. virens TRS106 in soil amended with wet (A, C) or lyophilized (B, D) microcapsules containing: chitosan $(\boldsymbol{\square})$, peat $(\boldsymbol{\Delta})$, skim milk $(\bullet)$, and alginate without additives $(\bullet)$. The vertical bars represent standard error of the means $(n=9)$. 
The efficacy of the produced microcapsules in control of Fusarium wilt of tomato plants was examined in the greenhouse experiment. For these studies, capsules supplemented with peat were chosen as material of the highest quality for commercial production. In all experiments, in the conditions of strong infection with $F$. oxysporum (80\% diseased plants compared to control), the best protective effect was obtained when microcapsules with bacteria PZ9 were used (Fig. 4). The effectiveness of this bacterium was comparable to fungicide (thiram). In the previous studies, the cell culture of PZ9 enhanced germination and reduced Fusarium wilt of tomato and cucumber plants in greenhouse experiments (Szczech 2009). The effect of SZ61 and CAT5 was lower. Trichoderma TRS106 entrapped in the capsules did not protect tomato plants. The treatments did not reduce pathogen density in the soil (Fig. 4). Fusarium density was reduced only when seeds were coated with fungicide. In other treatments, where the microcapsule-entrapped microorganisms were applied, the number of pathogen propagules increased, despite that, in other studies, CAT5 and PZ9 showed abilities to inhibit the pathogens growth (Szczech 2009). There are several reviews on the efficacy of encapsulated microorganisms as biocontrol agents or plant growth promoters (Bashan et al. 2002; John et al. 2011; Vemmer \& Patel 2013). However, there is little know about the influence of microcapsules on the pathogens population in soil, and further studies are needed.

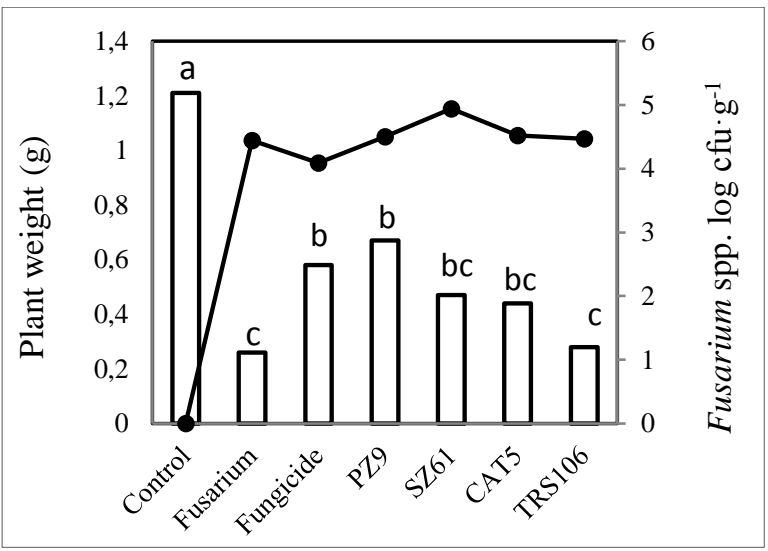

Fig. 4. Fresh weight (bars) of tomato seedlings and the number of Fusarium spp. propagules (line) in soil with microcapsules containing bacteria PZ9, SZ61, CAT5, and $T$. virens TRS106. The values are the means of 18 replications for plant weight and 9 replications for Fusarium number. The means of the plant weight with the same letters do not differ significantly according to DMRT at $\mathrm{p}=0.05$.

\section{CONCLUSIONS}

1. The emulsification of microbial culture with calcium alginate and plant oil is an easy technique to obtain microcapsules containing microorganisms.

2. The additives did not influence the microbial load in microcapsules and cell viability after processing and storage. However, they significantly affected the productivity and durability of the microcapsules: peat and chitosan increased yield and reduced capsule contamination, while skim milk addition to the alginate matrix had a negative effect on the microcapsules.

3. Peat used as an additive appeared as the most effective component, increasing the production of microcapsules and their storage ability.

4. Drying of the capsules by lyophilization did not improve their quality, but significantly reduced microbial load and increased production costs.

5. The productivity and quality of the microcapsules were related to the kind of used microorganisms.

6. The best properties and qualities for commercial use: high yield of microcapsules, good viability of entrapped cells during storage, and reduction of Fusarium wilt showed microcapsules containing bacteria Bacillus spp. strain PZ9.

\section{Acknowledgments}

The authors thank Prof. Piotr Sobiczewski for reviewing this manuscript. This study was supported by the Ministry of Agriculture and Rural Development, Poland, project no NN310119037.

\section{REFERENCES}

Atanasova L. 2014. Ecophysiology of Trichoderma in genomic perspective. In: Gupta V.K., Schmoll M., Herrera-Estrella A., Upadhyay R.S., Druzhinina I., Tuohy M.G. (Eds.), Biotechnology and biology of Trichoderma. Elsevier, pp. 25-40. DOI: 10.1016/B978-0-444-59576-8.00002-3.

Bashan Y. 1986. Alginate beads as synthetic inoculant carriers for slow release of bacteria that affect plant growth. Applied and Environmental Microbiology 51(5): 1089-1098.

Bashan Y. 1998. Inoculants of plant growth-promoting bacteria for use in agriculture. Biotechnology Advances 16: 729-770. 
Bashan Y., Gonzalez L.E. 1999. Long-term survival of the plant-growth-promoting bacteria Azospirillum brasilense and Pseudomonas fluorescens in dry alginate inoculant. Applied Microbiology and Biotechnology 51: 262-266. DOI: 10.1007/s002530051391.

Bashan Y., Hernandez J.P., Leyva-Macario Bacilio L.A. 2002. Alginate microbeads as inoculant carriers for plant growth-promoting bacteria. Biology and Fertility of Soils 35: 359-368. DOI: 10.1007/s00374-002-0481-5.

Cassidy M.B., Lee H., Trevors J.T. 1996. Environmental applications of immobilized microbial cells: a review. Journal of Industrial Microbiology 16: 79101. DOI: 10.1007/BF01570068.

Chan E.S., Wong S.L., Lee P.P., Lee J.S., Ti T.B., Zhang Z., Poncelet D., Ravindra P., Phan S.H., Yim Z.H. 2011. Effects of starch filler on the physical properties of lyophilized calcium-alginate beads and the viability of encapsulated cells. Carbohydrate Polymers 83: 225-232. DOI: 10.1016/j.carbpol.2010.07.044.

Cook M.T., Tzortzis G., Charalampopoulos D., Khutoryanskiy V.V. 2012. Microencapsulation of probiotics for gastrointestinal delivery. Journal of Controlled Release 162(1): 56-67. DOI: 10.1016/j.jconrel.2012.06.003.

van Elsas J.D., Trevors J.T., Jain D., Wolters A.C., Heijnen C.E., van Overbeek L.S. 1992. Survival of, and colonization by, alginate-encapsulated Pseudomonas fluorescens cells following introduction into soil. Biology and Fertility of Soils 14: 14-22. DOI: 10.1007/BF00336297.

Guo L., Wu Z., Rasool A., Li C. 2012. Effects of free and encapsulated co-culture bacteria on cotton growth and soil bacterial communities. European Journal of Soil Biology 53: 16-22. DOI: 10.1016/j.ejsobi.2012.08.003.

Hunt N.C., Grover L.M. 2010. Cell encapsulation using biopolymer gels for regenerative medicine. Biotechnology Letters 32: 733-742. DOI: 10.1007/s10529-010-0221-0.

John R.P., Tyagi R.D., Brar S.K., Surampalli R.Y., Prévost D. 2011. Bio-encapsulation of microbial cells for targeted agricultural delivery. Critical Reviews in Biotechnology 31(3): 211-226. DOI: 10.3109/07388551.2010.513327.

Kim I.Y., Pusey P.L., Zhao Y., Korban S.S., Choi H., Kim K.K. 2012. Controlled release of Pantoea agglomerans E325 for biocontrol of fire blight disease of apple. Journal of Controlled Release 161: 109-115. DOI: 10.1016/j.jconrel.2012.03.028.

Komada H. 1975. Development of a selective medium for quantitative isolation of Fusarium oxysporum from natural soil. Review of Plant Protection Research 8: 114-125.

Krasaekoopt W., Bhandari B., Deeth H. 2003. Evaluation of encapsulation techniques of probiotics for yoghurt. International Dairy Journal 13(1): 3-13. DOI: 10.1016/S0958-6946(02)00155-3.

Krasaekoopt W., Bhandari B., Deeth H. 2004. The influence of coating materials on some properties of alginate beads and survivability of microencapsulated probiotic bacteria. International Dairy Journal 14(8): 737-743. DOI: $10.1016 /$ j.idairyj.2004.01.004.

Lin J., Yu W., Liu X., Xie H., Wang W., Ma X. 2008. In vitro and in vivo characterization of alginate-chitosan-alginate artificial microcapsules for therapeutic oral delivery of live bacterial cells. Journal of Bioscience and Bioengineering 105: 660-665. DOI: $10.1263 /$ jbb.105.660.

Martin J.P. 1950. Use of rose bengal and streptomycin in the plate method for estimating soil fungi. Soil Science 69: 215-232.

Minaxi Saxena J. 2011. Efficacy of rhizobacterial strains encapsulated in nontoxic biodegradable gel matrices to promote growth and yield of wheat plants. Applied Soil Ecology 48: 301-308. DOI: 10.1016/j.apsoil.2011.04.007.

Morgan C.A., Herman N., White P.A., Vesey G. 2006. Preservation of micro-organisms by drying: a review. Journal of Microbiological Methods 66: 183-193. DOI: 10.1016/j.mimet.2006.02.017.

Nawrocka J., Snochowska M., Gajewska E., Pietrowska E., Szczech M., Małolepsza U. 2011. Activation of defense responses in cucumber and tomato plants by selected Polish Trichoderma strains. Vegetable Crops Research Bulletin 75: 105-116. DOI: 10.2478/v10032-011-0022-6.

Ogbonna J.C., Matsumura M., Kataoka H. 1991. Effective oxygenation of immobilized cells through reduction in bead diameters: a review. Process Biochemistry 26(2): 109-121. DOI: 10.1016/00329592(91)80025-K.

Onwulata C.I. 2012. Encapsulation of new active ingredients. Annual Review of Food Science and Technology 3: 183-202. DOI: 10.1146/annurevfood-022811-101140.

Özer B., Uzun Y.S., Kirmaci H.A. 2008. Effect of microencapsulation on viability of Lactobacillus acidophilus LA-5 and Bifidobacterium bifidum BB-12 during kasar cheese ripening. International Journal of Dairy Technology 61(3): 237-244. DOI: 10.1111/j.1471-0307.2008.00408.x.

Rathore S., Desai P.M., Liew C.V., Chan L.W., Sia Heng P.W. 2013. Microencapsulation of microbial cells. 
Journal of Food Engineering 116: 369-381. DOI: 10.1016/j.jfoodeng.2012.12.022.

Schisler D.A., Sliniger P.J., Behle R.W., Jackson M.A. 2004. Formulation of Bacillus spp. for biological control of plant diseases. Phytopathology 94: 12671271. DOI: 10.1094/PHYTO.2004.94.11.1267.

Semyonov D., Ramon O., Kaplun Z., Levin-Brener L., Gurevich N., Shimoni E. 2010. Microencapsulation of Lactobacillus paracasei by spray freeze drying. Food Research International 43: 193-202. DOI: 10.1016/j.foodres.2009.09.028.

Szczech M. 2009. Biologiczna ochrona roślin warzywnych przy użyciu mieszanek aktywnych mikroorganizmów. Report no 2P06R08430, Instytut Warzywnictwa, Skierniewice, 35 p. [in Polish].

Szczech M., Dyki B. 2007. Combination of microbial biocontrol agents to control rhizoctonia dampingoff and fusarium with of tomato. IOBC/WPRS Bulletin 30(6): 415-418.

Szczech M., Dyśko J. 2008. The possibility to use selected mixtures of PGPR bacteria in tomato cultivation. Vegetable Crops Research Bulletin 68: 47-56. DOI: 10.2478/v10032-008-0004-5.

Szczech M., Kowalska B., Dyki B., Horbowicz M., Kowalczyk W. 2009. Microbial mixtures enhancing plant resistance to pathogen stress. IOBC/WPRS Bulletin 43: 89-94.

Szczech M., Małolepsza U., Witkowska D., Gajewska E., Piegza M., Pietrowska E. i in. 2011. System selekcji grzybów Trichoderma do wykorzystywania w rolnictwie. Ogólnopolska Konferencja Naukowa „Trichoderma i inne grzyby w nauce i praktyce”, Radziejowice, pp. 20-21 [in Polish].

Szwejda-Grzybowska J., Kosson R., Tuszyńska M., Dyśko J., Szczech M. 2015. Wpływ uprawy na podłożu zawierającym grzyby Trichoderma na wartość odżywczą owoców pomidora. II Konferencja Naukowa „Biostymulatory w nowoczesnej uprawie roślin”, Warszawa, 130 p. [in Polish].

Trevors J.T., van Elsas J.D., Lee H., van Overbeek L.S. 1992. Use of alginate and other carriers for encapsulation of microbial cells for use in soil. Microbial Releases 1: 61-69.

Tripathi M.K., Giri S.K. 2014. Probiotic functional foods: Survival of probiotics during processing and storage. Journal of Functional Foods 9: 225-241. DOI: 10.1016/j.jff.2014.04.030.

Vemmer M., Patel A.V. 2013. Review of encapsulation methods suitable for biological control agents. Biological Control 67: 380-389. DOI: 10.1016/j.biocontrol.2013.09.003.

Winder R.S., Wheeler J.J., Conder N., Otvos I.S., Nevill R., Duan L. 2003. Microencapsulation: a strategy for formulation of inoculum. Biocontrol Science and Technology 13: 155-169. DOI: 10.1080/0958315021000073439.

Wu B.J., Thompson S.T. 1984. Selective medium for Pseudomonas cepacia containing 9-chloro-9(4diethylaminophenyl)-10-phenylacridan and polymyxin B sulfate. Applied and Environmental Microbiology 48: 743-746.

Yabur R., Bashan Y., Hernández-Carmona G. 2007. Alginate from the macroalgae Sargassum sinicola as a novel source for microbial immobilization material in wastewater treatment and plant growth promotion. Journal of Applied Phycology 19: 43-53. DOI: 10.1007/s10811-006-9109-8.

Young C.C., Rekha P.D., Lai W.A., Arun A.B. 2006. Encapsulation of plant growth-promoting bacteria in alginate beads enriched with humic acid. $\mathrm{Bi}-$ otechnology and Bioengineering 95(1): 76-83. DOI: 10.1002/bit.20957. 